\title{
FUNCTIONAL RESULTS AFTER OPERATIVE TREATMENT OF TALUS FRACTURES
}

\author{
Andreja Gavrilovski¹, Aleksandra Dimovska-Gavrilovska², Goran Aleksovski \\ University Clinic for Traumatology, Orthopedics, Anesthesiology, Reanimation and Intensive Care Skopje; Ss. \\ Cyril and Methodius University, Faculty of Medicine, Skopje, Republic of North Macedonia \\ 2 University Clinic for Neurosurgery, Ss. Cyril and Methodius University, Faculty of Medicine, Skopje, Republic of \\ North Macedonia
}

\begin{abstract}
Citation: Gavrilovski A, Dimovska-Gavrilovska A, Aleksovski A. Functional results after operative treatment of talus fractures. Arch Pub Health 2021; 13 (1).

doi.org/10.3889/aph.2021.5723

Key words: talus fracture, surgical treatment, ORIF, functional outcome.

*Correspondence: Andreja Gavrilovski. University Clinic for Traumatology, Orthopedics, Anesthesology, Reanimation and Intensive Care Skopje; Ss. Cyril and Methodius University, Faculty of Medicine, Skopje, Republic of North Macedonia. E-mail: gavrilovskia@yahoo.com

Received: 5-Jan-2021; Revised: 27-Feb-2021; Accepted: 3-Mar-2021; Published: 10-Mar-2021 Copyright: ${ }^{\odot}$ 2021. Andreja Gavrilovski, Aleksandra Dimovska-Gavrilovska, Goran Aleksovski. This is an Dimovska-Gaviris distributed under the terms open-access aticle distributed under the terms of the Creative Commons Attribution License, which permits unrestricted use, distribution, and reproduction in any medium, provided the original author(s) and source are credited

Competing Interests: The author have declared hat no competing interest
\end{abstract}

\section{Клинички ипспитувања}

\begin{abstract}
Fractures of the talus do not occur frequently, accounting for about $0.1 \%$ of all fractures. Failure to achieve anatomic reduction, exponentially increases the risk of postoperative aseptic osteonecrosis and posttraumatic osteoarthritis. The purpose of this study was to evaluate and compare the short-term and medium-term functional outcomes in patients who underwent open reduction and internal fixation of talus fractures. Material and methods: At the University Clinic for Traumatology in the period between 2017 to 2020, 14 patients with talus fractures were surgically treated. The inclusion and exclusion factors were determined, all patients signed the consent and the study passed the ethics committee. Results: All patients underwent open reduction and internal fixation with screws or reconstructive plate. Follow-up was done on the $14^{\text {th }}$ postoperative day, 1st month, $3^{\text {rd }}$ month and $6^{\text {th }}$ month. At the 6 th month follow-up, the functional outcome was tested using the Kitaoka score unified by the American Orthopedic Foot and Ankle Society. This injury is too rare for conclusions to be brought out of and to be compared to larger studies. Anatomical reduction is mandatory for a better outcome. Conclusion: A protocol for the treatment of posttraumatic osteoarthritis should be introduced, given the high rate of its occurrence despite the satisfactory surgical technique.
\end{abstract}

Цитирање: Гавриловски А, Димовска-Гавриловска А, Алексовски Г. Функционални реловска А, Алексовски Г. Функционални резултати по оперативен третман

doi.org/10.3889/aph.2021.5723

Клучни зборови: фрактура на талус, хируршки третман, функционален резултат

*Кореспонденција: Андреја Гавриловски, Универзитетска клиника за трауматологија, ортопедија, анестезија, реанимација и интензивно лекување- Скопје, Република Северна Македонија. E-mail:gavrilovskia@yahoo.con

Примено: 5-јан-2021; Ревидирано: 27-фев-2021; Прифатено: 3-мар-2021; Објавено: 10-мар-2021

Печатарски права: ${ }^{2021}$ Андреја Гавриловски , Александра Димовска-Гавриловска, Горан Алексовски. Оваа статија е со отворен пристап дистрибуирана под условите на нелокализирана лиценца, која овозможува неограничена употреба, дистрибуција и репродукција на било кој медиум, доколку се цитираат оригиналниот(ите) автор(и) и изворот.

Конкурентски интереси: Авторот изјавува дека нема конкурентски интереси.

\section{Извадок}

Фрактурите на талусот не се случуваат често, и тие претставуваат околу 0,1\% од сите фрактури. Доколку не се постигне анатомска редукција, процентот на постоперативна асептична остеонекроза и посттрауматски остеоартритис се зголемува експонецијално. Целта на оваа студија беше да се евалуираат и споредат краткорочните и среднорочните функционални резултати кај пациенти со фрактури на талус кај кои беше направена отворена редукција и внатрешна фиксација. Материјал и методи: На Универзитетската клиника за трауматологија во периодот од 2017 до 2020 година хирушки беатретирани 14 пациенти со фрактура на талусот. Инклузионите и ексклузионите фактори беа детерминирани; сите пациенти потпишаа писмена согласност за учество во студијата и студијата беше одобрена од страна на Етичката комисија на Медицинскиот факултет. Резултати: Кај сите пациенти беше направена отворена крвава репозиција и фиксација со шрафови или реконструктивна плочка. Кај сите пациентите беше направена амбулантска контрола 14-тиотпостоперативен ден, 1-виот месец, 3-тиот месец и 6-тиот месец. Во текот на амбулантската контрола 6-тиот месец кај сите се правеше објективно и функционално тестирање на функцијата на зглобот. За таа примена го одбравме Kitaoka score унифициран од American Orthopaedic Foot and Ankle Society. Оваа повреда е многу ретка за да се изнесат и споредат поголеми студии. Сепак, сите поголеми студии од референтни траума центри водат кон истиот заклучок, а тоа е дека третманот на овие фрактури е комплексен. Постигнувањето на анатомска редукција е важно за подобар исход. Заклучок: Треба да се воведе некој протокол за третман на посттрауматскиот остеоартрит, со оглед на високиот процент на негово појавување и покрај задоволителната оперативна техника. 


\section{Introduction}

Fractures of the talus do not occur frequently, accounting for about $0.1 \%$ of all fractures. They are divided into 3 groups: fractures of the body, neck and head of the talus. The fractures of the neck account for about $50 \%$ of all talus fractures, or $45 \%$ according to a study by Elgafy et $a l^{1}$. Proper treatment of these fractures is a major challenge from multiple aspects. Due to the fact that most of the surface is articular and loading, it is necessary to reduce the talar fractures anatomically. Failure to achieve anatomic reduction exponentially increases the risk of postoperative aseptic osteonecrosis and posttraumatic osteoarthritis. To plan the proper treatment of the above-mentioned fractures, certain important features of the talus have tobe noted. The talus occupies a significant and central place in the tarsus, without which the movements in the ankle would not have taken place and the weight would not have been properly distributed to the other bones in the front of the foot. It is important to mention:

\section{Anatomical features}

The talus is composed of body, head and neck. The talus has multiple articular surfaces. In the upper part of the body, it is articulated with the tibia and fibula, in the lower part of the body with the calcaneus, while in the front part with the head with the normal bone. There are no muscle-tendon attachments on this bone. The biomechanical role of this tarsal bone is transferred to the forces of the lower leg.
1. Specific and vascularity

The blood supply to the talus is highly specific since almost $60 \%$ of its surface is cartilaginous; only a small portion of the talus may be perforated by blood vessels. There is a ring of blood vessels around the head and neck of the talus, consisting of the anterior and posterior tibial artery and perforated peroneal arteries. If those areas of nutritional artery entry are disrupted, avascular necrosis and subsequent ankle arthrosis can easily occur ${ }^{2}$. The most common mechanism for these fractures to occur is forced dorsiflexion with axial loading. Accompanying fractures may be bimalleolar fractures, namely medial malleolar fractures.

The purpose of this study was to evaluate and compare the shortterm and medium-term functional outcomes in patients who underwent open reduction and internal fixation of talus fractures.

\section{Materials and methods}

In the period between 2017 and2020, 14 patients with talus fractures were surgically treated at the University Clinic for Traumatology. Of these, 10 were male patients and 4 female patients. The mean age of the patients was 44 years. Only patients who met the inclusion criteria, operatively treated fractures, and signed consent to participate in the study were included in this study.

The study included patients with talus fractures who met the following inclusion factors: 
- No more than 2 comorbidities;

- No open fracture;

- No previous disability of the injured limb;

- Isolated trauma to the talus without accompanying injuries.

All fractures were classified according to the Hawkins classification ${ }^{3}$. According to it, the fractures are divided into 4 groups:

- Type 1 - unlocated fracture;

- Type 2 - dislocated fracture with displacement of the subtalar joint;

- Type 3 - dislocated fracture with subtalar luxation and ankle luxation;

- Type 4 - dislocated fracture with subtalar luxation, ankle luxation, and talonavicular dislocation.

\section{Results}

According to the above-mentioned classification, we had:

- Type 1 - 2 patients (1 male, 1 female);

- Type 2 - 9 patients (8 male, 1 female);

- Type 3 - 3 patients (1 male, 2 female).

The classification was made on the basis of computed tomography images taken from all patients. Of the 14 patients, 5 had an associated fracture of the medial malleolus.

All patients underwent open reduction and internal fixation with screws (Picture 1) or reconstructive plate (Picture 2). Postoperatively all patients had immobilization during the next 14 days. Three patients underwent revision due to an inad- equate primary reduction seen on the postoperative CT scans.

All patients were postoperatively treated with LMWH, antibiotic therapy for 5 days, and analgesic therapy.

Follow-up was done on the $14^{\text {th }}$ postoperative day, $1^{\text {st }}$ month, $3^{\text {rd }}$ month and $6^{\text {th }}$ month. X-rays were taken on the $1^{\text {st }}$ month, $3^{\text {rd }}$ month and $6^{\text {th }}$ month, except on the first follow-up, where the sutures were removed.

At the $6^{\text {th }}$ month follow-up, the functional outcome was tested using the Kitaoka score unified by the American Orthopedic Foot and Ankle Societ ${ }^{4}$. The following nine parameters were evaluated:

1. Pain - (no pain, mild pain, intermittent pain, persistent pain);

2. Function - (without restrictions or walking using a helping device);

3. Walking distance - (from being able to walk less than $1 \mathrm{~km}$ to more than $6 \mathrm{~km}$ );

4. Terrain - (flat, stairs, mountain);

5. Walking abnormalities;

6. Sagittal movement (extension and flexion);

7. Eversion and inversion;

8. Foot stability (anteroposterior, varus/valgus);

9. Alignment of the foot and ankle.

The maximum score of the Kitaoka score system is 100 points, excellent (100-85), good (85-65), unsatisfactory $(65-45)$ and bad $(>45)^{5}$. 
Of the 14 respondents, excellent result had 2 patients (mean result of 86.5), and good result was found in 8 patients (mean result of 68).An unsatisfactory result had 3 patients (mean score of 48.5) and a bad result in one patient (38 points).
Early complications were postoperative skin problems (areas of necrosis in the area of the operative wound) in 4 patients.

Late complications were posttraumatic osteoarthritis (6 patients) and avascular necrosis (4 patients).
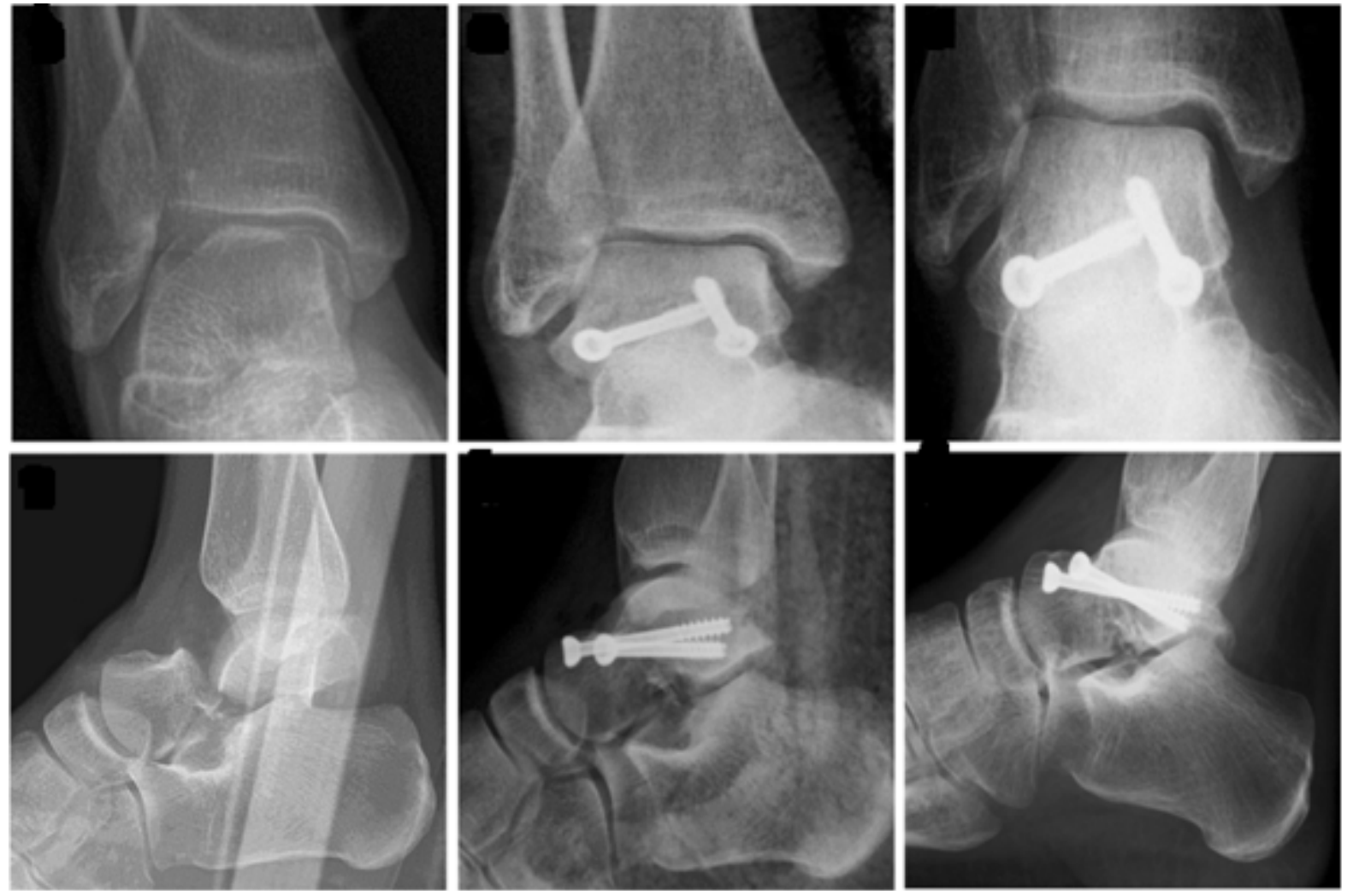

Picture 1. Osteosynthesis with

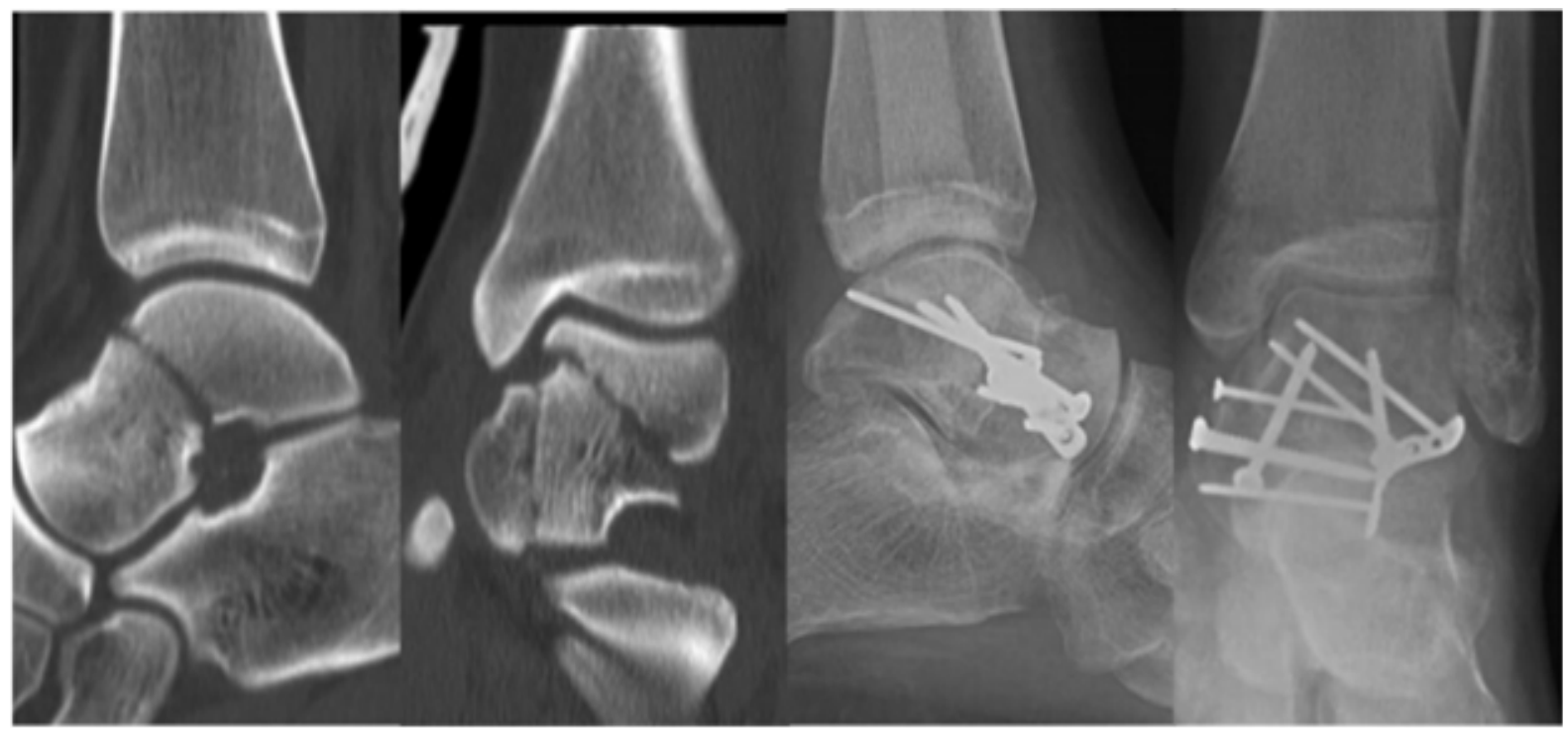

Picture 2. Osteosynthesis with reconstructive plate 


\section{Discussion}

This injury is too rare for conclusions to be brought out and to be compared to larger studies. However, all major studies from reference trauma centers lead to the same conclusions that the treatment of these fractures is complex. It depends a lot on achieving absolute anatomical reduction, but the outcome may still be unsatisfactory due to the complex biology of this tarsal bone.

According to a study by Halvorsen et al., published in 2013, the percentage of avascular necrosis of the talus changed according to the Hawkins fracture classification type. A total of 848 patients finished the followup, and determined that incidence of avascular necrosis occurrence was 5.7\%in type $1,18.4 \%$ in type 2 , and type 3 increased to $44.7 \%$. For Hawkins type 4 , due to the rarity of the injury, it was inconclusive to bring a satisfactory conclusion ${ }^{6}$.

In 2014, Fournier et al. conducted a multicenter study of 114 cases of talar fractures operated in various centers? ${ }^{7}$. The results were rather overwhelming $-40 \%$ of the patients had unsatisfactory results compared to only $10 \%$ excellent. Avascular necrosis occurred in 39 of the cases, and posttraumatic osteoarthritis in $74 \%$ of the cases. In another study conducted in 2017, Barnett et al. confirmed the above-mentioned results of Fournier and his coworkers. But, they emphasized that time was a crucial factor in the treatment of these fractures. If the nutritional part of the talus is fractured, it should be operated on in the first 24 hours following injury ${ }^{8,9}$.

\section{Conclusion}

At our Clinic, time till surgery is not taken into account as a direct factor to the outcome of the treatment of certain types of talar fractures. Anatomical reduction is mandatory for a better outcome. A protocol for the treatment of posttraumatic osteoarthritis should be introduced, given the high rate of its occurrence despite the satisfactory surgical technique.

\section{References}

1. Elgafy $\mathrm{H}$, Ebraheim NA, Tile M, Stephen D, Kase J. Fractures of the talus: experience of two level 1 trauma centers. Foot Ankle Int 2000;21(12): 1023-1029. doi : 10.1177 / 107110070002101208.

2. Adelaar RS, Madrian JR. Avascular necrosis of the talus. Orthop Clin North Am 2004;35(3): 383-395. doi: 10.1016/j.ocl.2004.02.010.

3. Dale JD, Ha AS, Chew FS. Update on talar fracture patterns: a large level I trauma center study. AJR Am J Roentgenol 2013;201(5): 1087-1092. doi: 10.2214/AJR.12.9918.

4. Kitaoka HB, Alexander IJ, Adelaar RS, Nunley JA, Myerson MS, Sanders M. Clinical rating systems for the ankle-hindfoot, midfoot, hallux, and lesser toes. Foot Ankle Int 1994;15: 349-353.

5. Allier HA, Reichard SG, Boyd AJ, Moore TA. A new look at the Hawkins classification for talar neck fractures: which features of injury and treatment are predictive of osteonecrosis? J Bone Joint Surg Am 2014;96(3): 192-197. doi: 10.2106/ JBJS.L.01680.

6. Halvorson JJ, Winter SB, Teasdall RD, Scott AT. Talar neck fractures: a 
systematic review of the literature. J Foot Ankle Surg 2013;52(1):56-61. doi: 10.1053/j.jfas.2012.10.008.

7. Fournier A, Barba N, Steiger V, Lourdais A, Frin JM, Williams T et al. Total talar fracture - long-term results of internal fixation of talar fractures. A multicentric study of 114 cases. Orthop Traumatol Surg Res. 2012;98(4)Suppl:S48-S55. doi: 10.1016/j.otsr.2012.04.012.

8. Barnett JR et al. The diagnosis, management and complications associated with fractures of the talus. The Open Orthopedic Journal 2017; 11: 460-466. doi: 10.2174/1874325001711010460.

9. Cebesoy O, Karakurum G. Talar fractures and avascular necrosis. Are we underestimating the risk? Int Orthop 2007;31(2): 269. doi: 10.1007/ s00264-006-0239-z. 